Agricultural Journal 5 (1): 1-5, 2010

ISSN: $1816-9155$

(C) Medwell Journals, 2010

\title{
Economic Viability of Replacing Maize with Whole Cassava Root Meal in the Diet of Hybrid Cat-Fish
}

\author{
${ }^{1}$ O.M.G. Abu, ${ }^{2}$ L.O. Sanni, ${ }^{3}$ E.S. Erondu and ${ }^{4}$ O.A. Akinrotimi \\ ${ }^{1}$ Rivers State Agricultural Development Programme, Rumuodomaya, \\ Port Harcourt, Rivers State, Nigeria \\ ${ }^{2}$ Department of Crop Production, University of Agriculture, \\ Abeokuta, Ogun State, Nigeria \\ ${ }^{3}$ Department of Animal Science and Fisheries, University of Port Harcourt, \\ Port Harcourt, Rivers State, Nigeria \\ ${ }^{4}$ African Regional Aquaculture Centre, Nigeria Institute for Oceanography and Marine Research, \\ P.M.B. 5122, Port Harcourt, Rivers State, Nigeria
}

\begin{abstract}
This study was conducted to assess the economic viability of replacing maize with whole cassava root meal in the diet of hybrid cat-fish. The results from the study indicated that the average total cost per $\mathrm{kg}$ of fish was N $180.05 \mathrm{k}$ and the average total revenue per $\mathrm{kg}$ of fish was N379.62 k. This gives a Gross Margin $(\mathrm{GM})$ of N202.72 k per $\mathrm{kg}$ of fish produced. Also from the results, the average net revenue was found to be $\mathrm{N} 207.07 \mathrm{k}$ per $\mathrm{kg}$ of fish. The sum total of elasticities of variables was less than unity (i.e., 0.801 ), which indicates that replacement of maize with cassava in fish production is in stage II, which is in the rational stage of production. The cost benefit analysis showed that the lowest incidence of cost, highest profit index, the least expenditure, the highest sale, net profit and cost benefit ratio were observed in diet $D_{100}$, closely followed by $\operatorname{diet} \mathrm{C}_{66}$. It could therefore be concluded that whole cassava root meal can replace maize in the diet of hybrid catfish effectively up to $100 \%$ with the optimal performance of $66 \%$ level of inclusion. Fish farmers can therefore explore the use of cassava as an alternative to maize meal in hybrid catfish diet with better profit margins.
\end{abstract}

$\underline{\text { Key words: Economic, viability, profit, fish production, hybrid cat-fish, cassava, maize }}$

\section{INTRODUCTION}

Hybrid Catfish (Clarias $\mathrm{x}$ Heterobranchus) is one of the most important catfish specie cultured in Nigeria. It is very popular among the fish farmers as it combines the favourable culture characteristics of the two species. The need to intensify the culture of the fish, so as to meet the ever increasing demand for fish has made it essential to develop suitable diets either in supplementary forms for ponds or as complete feed in tanks (Olukunle, 2006). For the purpose of nutritional and economic benefits, previous researchers have made attempts at increasing the use of non-conventional plant and animal material to replace conventional feed ingredients like maize and fish meal in fish feed ration (Olatunde, 1996; Olukunle, 1996; Eyo, 2004).

According to Olurin et al. (2006) maize is the major source of metabolisable energy in most compounded diets for catfish species. This is because it is readily available and digestible. However, the increasing prohibitive cost of this commodity has necessitated the need to search for an alternative ingredient that will serve as a replacement.

In aquaculture, feeding of fish has been acknowledged generally contributes as the major cost incurred during the production cycle (Eyo, 2003; Jamu and Ayinla, 2003; Akinrotimi et al., 2007). For instance, Gabriel et al. (2007) reported that feed alone in fish farming accounted for between $60-70 \%$ of the running expense involved in the operation of fish farm as an enterprise. And this in most cases reduced the profit of the farmer which often results into marginal profit, Bekibele et al. (2006) observed that cost of feed as a factor has been recognized as a major factor affecting the development and expansion of aquaculture enterprise in many African countries. This situation has contributed in no small measure to the drastic decline in fish and livestock production due to high cost of feeding, with a resultant short fall in protein intake of the people in many developing countries (Adejinmi, 2000). Cereals especially maize has been the major source of energy in fish diets

Corresponding Author: O.M.G. Abu, Rivers State Agricultural Development Programme, Rumuodomaya, Port Harcourt, Rivers State, Nigeria 
and it is about $10-40 \%$ by weight in most aquafeeds. The high cost and scarcity of maize in formulated feeds has led to the use of underutilized energy sources such as cassava root meal, cassava leaf meal, wheat bran and sorghum meal (Osuigwe et al., 2005). Therefore, partial or total replacement of maize with cassava root meal could be of considerable economic advantage. However, the economic feasibility of utilization of cassava root meal in fish feed lies in the fact that cassava meal is of comparable quality with maize (Jiang, 2001; Booth and Allan, 2003; Tewe, 2004) cheaper than maize (Akinfala and Tewe, 2001; Ijaiya et al., 2002; Fasuyi and Aletor, 2005) and more readily available than maize (Odunsi et al., 2001).

Improving the basis for the assessment of ingredients cost and availability is perhaps one of the key issues in maximizing opportunities for optimal use of feed ingredients as replacement in feed formulation for aquaculture enterprise.

While there have been substantial advances in this area in recent years, there is a clear need to improve out understanding of the processes of interactions among cost of ingredients, nutrient and processing and how these influence economic viability.

This study therefore is aimed at studying the economic viability of partial and total replacement of maize with whole cassava root meal in the diet of hybrid catfish. A popular fish for culture in Nigeria, which hitherto has not been reported. As the rapidly growing aquaculture industry will increasingly need to utilize information of this type to formulate a cost effective feed for the sustainability of aquaculture venture.

\section{MATERIALS AND METHODS}

This research was carried out at the International Institute for Tropical Agriculture (IITA) Onne, Rivers State, Nigeria. Fingerlings of hybrid catfish were reared in each of 12 concrete tanks of dimension $(2.5 \times 2 \times 1.3 \mathrm{~m})$ for a period of 32 weeks to determine the economic viability of replacing maize with cassava in the diet of this species of fish.

Four practical diets were produced and labeled $\mathrm{A}_{0}$, $\mathrm{B}_{33}, \mathrm{C}_{66}$ and $\mathrm{D}_{100}$. In these diets, maize was substituted with whole cassava root meal at graded levels of 33,66 and $100 \%$, respectively. Each diet were fed to the fish in tanks labeled differently.

The fish were reared from fingerlings to table size (average weight of $1.2 \mathrm{~kg}$ ) and sold off. The economic evaluation of substituting maize with cassava root meal in the culture of hybrid catfish was then evaluated. The benefit of the various diets was determined using the following indices:

$$
\begin{gathered}
\text { Incident of } \cos \mathrm{t}=\frac{\text { Cost of feed }}{\text { Weight of fish produces }} \\
\text { Profitindex }=\frac{\text { Weight or value of fish produced }}{\text { Cost of feed }} \\
\text { Net profit }=\text { Sales-Expenditure } \\
\text { Cost-Benefit ration }=\frac{\text { TotalSales }}{\text { TotalExpenditure }} \\
\text { TC }=\left(\text { kg }{ }^{-1}\right)=\frac{\text { Sales of the fish }}{\text { Weight of the fish }} \\
\text { TC }=\text { Fixed Cost }+ \text { Total Variable Cost } \\
\text { FC }=\text { Cost of Fingerlings }\left(\text { kg }{ }^{-1}\right) \\
\text { TVC }=\text { Cost of producing different diets } \\
(\text { Sogbesan and Ugwumba, 2006 })
\end{gathered}
$$

Gross margin analysis and profitability ratio were used to examine the cost and returns of fish production in replacing maize with whole cassava root meal, while production function was employed to determine the productivity of the experiment. Gross margin analysis is given by Eq. 5 :

Where:

$$
\mathrm{GM}=\mathrm{TR}-\mathrm{TVC}
$$

$\mathrm{GM}=$ Gross margin (N)

$\mathrm{TR}=$ Total Revenue (N)

$\mathrm{TVC}=$ Total variable $\operatorname{cost}(\mathrm{N})$

The performance and economic worth of various diets was determined by the use of the following:

$$
\mathrm{NR}=\mathrm{TR}-\mathrm{TC}
$$

Where:

NR $=$ Net Revenue

$\mathrm{TR}=$ Total Revenue

$\mathrm{TC}=$ Total Cost

The production function postulates for production in this research is implicitly presented by Eq. 11:

$$
Q=f\left(x_{1}, x_{2}, x_{3}, x_{4}, x_{5}, x_{6}, x_{7}, x_{8}, U_{1}\right)
$$

Where:

$\mathrm{Q}=$ Total Revenue (N)

$\mathrm{x}_{1}=$ Cost of feed (N) 
Agric. J., 5(1): 1-5, 2010

$\mathrm{x}_{2}=$ Size of $\operatorname{tank}(\mathrm{N})$

$\mathrm{x}_{3}=$ Initial weight of fish raised

$\mathrm{x}_{4}=$ Final weight of fish raised

$\mathrm{x}_{5}=$ Effects of $\operatorname{diet} \mathrm{A}_{0}$

$\mathrm{x}_{6}=$ Effects of $\operatorname{diet} \mathrm{B}_{33}$

$\mathrm{x}_{7}=$ Effects of $\operatorname{diet} \mathrm{C}_{66}$

$\mathrm{x}_{8}=$ Effects of $\operatorname{diet} \mathrm{D}_{100}$

$\mathrm{U}_{1}=$ Error term assume to have a zero mean and constant variance

These were evaluated using ordinary least square method.

\section{RESULTS AND DISCUSSION}

The cost of the experimental feed was highest in diet $\mathrm{A}_{0} 183.00 \mathrm{~kg}^{-1}$ and least in diet $D_{100} 176.00 \mathrm{~kg}^{-1}$. The cost of feeding in 32 weeks reduced as the inclusion of WCRM increased (Table 1). Total cost of fingerling purchased and feeding for the 32 weeks was $\$ 5,913.49$ in

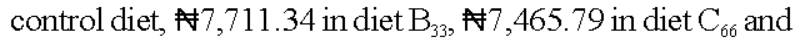
N5,938.18 in diet $D_{100}$ (Table 1). The cost benefit analysis indicated that the cost of production of control $\operatorname{diet}\left(\mathrm{A}_{0}\right)$ was higher than the cost of other dietary treatments throughout the experimental period, while the cost of diet $D_{100}$ was the least (Fig. 1). Though, sales values were highest in diet $\mathrm{C}_{66}$ and lowest in $\operatorname{diet} \mathrm{A}_{0}$, the benefit/cost was highest in diet $\mathrm{B}_{33}(1.68: 1)$ and lowest (1.55:1) in diet $D_{100}$ (Table 1). The average total cost per $\mathrm{kg}$ of fish produced was $180.00 \mathrm{k}$, while the average total revenue per kilogram of raised fish was $379.62 \mathrm{k}$. And the average values of gross margin and net revenue are 202.72 and 207.07, respectively (Table 2). The elasticity of production was shown in Table 3 . The total sum was less than unity that is 0.801 indicating decreasing returns to scale.

The economic viability of replacement of maize with whole cassava root meal indicated that the cost of the diets reduce as the quantity of maize was being replaced with whole cassava root meal. This supports the reports of Chalorwang et al. (2000), who observed same in channel catfish fed with varying levels of cassava root meal in replacement of maize. They reported that cereals especially maize constitute about $10-40 \%$ of aqua feed and considering the increasing cost of maize especially in developing countries, the need to replace maize is highly imperative. The best cost benefit was obtained in $\operatorname{diet} \mathrm{B}_{33}$ and best net profit was obtained in $\operatorname{diet} \mathrm{C}_{66}$. Economic viability of feeding hybrid catfish indicated that cost of feeding, net profit and returns were good in $\operatorname{diet} \mathrm{C}_{66}$. The
Table 1: Economic viability of replacing maize with whole cassava root meal in the diet of hybrid catfish

\begin{tabular}{lllll}
\hline Parameters & \multicolumn{1}{c}{$\mathrm{A}_{0}$} & \multicolumn{1}{c}{$\mathrm{B}_{33}$} & \multicolumn{1}{c}{$\mathrm{C}_{66}$} & $\mathrm{D}_{100}$ \\
\hline Cost of feed kg & 183.000 & 182.000 & 178.000 & 176.000 \\
Feed input (kg) & 20.1800 & 30.1700 & 29.4700 & 31.1300 \\
Cost of feeding (N) & $6,693.49$ & $5,491.34$ & $5,245.79$ & $3,718.18$ \\
Cost of fingerlings (N) & $2,220.00$ & $2,220.00$ & $2,220.00$ & $2,220.00$ \\
Total cost (N) & $8,913.49$ & $7,711.34$ & $7,465.79$ & $6,938.18$ \\
Harvested (kg) & 25.3500 & 31.70000 & 33.75000 & 27.6500 \\
Sales @ 600 kg & 15,2100 & 19,02000 & 20,25000 & 16,5900 \\
Returns (N) & $9,296.51$ & $11,308.66$ & $12,784.22$ & $10,651.82$ \\
Benefit-cost ratio & 1.94000 & 1.680000 & 1.5800000 & 1.550000 \\
\hline
\end{tabular}

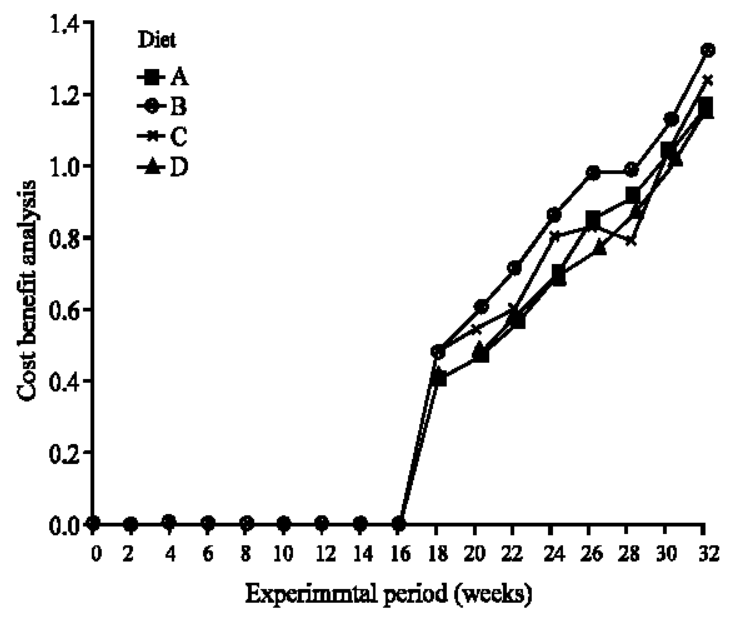

Fig. 1: Effect of replacement of maize with Cassava on the cost-benefit of raising hybrid catfish

best cost benefit was recorded in diet $\mathrm{D}_{100}$, this agreed with the report of Jinyasataporn et al. (2000), who observed the best profit margin in C. gariepinus fed with $100 \%$ of cassava root meal in replacement of maize. This is because cassava is far cheaper than maize.

The Benefit Cost Ratio (BCR) obtained in this research were within the profit margin. According to Adegeye and Dittoh (1982), this ratio is one of the concepts of discount method of project evaluation.

As a rule of thumb, project with benefit cost ratio greater than one, equal to one or less than one indicate profit break-even or loss respectively (Olagunju et al., 2007), since the ratio in the diets is above one. It shows that replacing maize with cassava is highly profitable.

On the average the gross margin was high in all the diets replacing cassava at various levels than one with only maize meal. According to Olagunju et al. (2007), Gross Margin is a good measure of profitability, therefore replacement of maize meal with cassava root meal in the diet of hybrid cat fish is highly profitable. Diet $D_{100}$, which has the highest gross margin of $218.48 \mathrm{k}$. This implies that it had minimum variable cost of production coupled 
Agric. J., 5(1): 1-5, 2010

Table 2: Gross margin and net return analysis of fish production

\begin{tabular}{|c|c|c|c|c|c|c|}
\hline Diet & TVC $\left(\mathrm{Ng}^{-1}\right)$ & $\mathrm{FC}\left(\mathrm{kg}^{-1}\right)$ & $\mathrm{TC}\left(\mathrm{Ng}^{-1}\right)$ & $\mathrm{TR}\left(\mathrm{kg}^{-1}\right)$ & $\mathrm{GM}\left(\mathrm{kg}^{-1}\right)$ & $\mathrm{NR}\left(\mathrm{kg}^{-1}\right)$ \\
\hline$\overline{A_{0}}$ & 183.00 & 0.30 & 183.30 & 371.84 & 188.84 & 208.54 \\
\hline $\mathrm{B}_{33}$ & 182.00 & 0.30 & 182.30 & 374.77 & 192.77 & 192.47 \\
\hline $\mathrm{C}_{66}$ & 178.00 & 0.30 & 178.30 & 378.39 & 209.39 & 209.09 \\
\hline$D_{100}$ & 176.00 & 0.30 & 176.30 & 394.48 & 218.48 & 218.18 \\
\hline Total & 179.75 & 0.30 & 180.05 & 379.62 & 202.72 & 207.07 \\
\hline
\end{tabular}

Table 3: Elasticity of production and return to scale of different diets feed hybrid cat fish

\begin{tabular}{lc}
\hline Independent variables & Elasticity of production \\
\hline $\mathrm{x}_{1}$ & 0.011 \\
$\mathrm{x}_{2}$ & -0.066 \\
$\mathrm{x}_{3}$ & 0.013 \\
$\mathrm{x}_{4}$ & 0.018 \\
$\mathrm{x}_{5}$ & 0.056 \\
$\mathrm{x}_{6}$ & 0.021 \\
$\mathrm{x}_{7}$ & 0.042 \\
$\mathrm{x}_{8}$ return to scale & 0.801 \\
\hline
\end{tabular}

with low fixed cost hence the highest return it recorded. This is in line with the findings of Fagbenro et al. (2001), who assumed similar results in the diet of nile tilapia (Oreochromis niloticus).

\section{CONCLUSION}

The results obtained from this study revealed the fact that whole cassava root meal is a profitable alternative energy source for partial or total replacement of maize in feeding of cat fish hybrid. It also indicated that cassava, which is readily available can replace maize up to $100 \%$. It is therefore said that fish farmers be encouraged to use cassava root meal as an alternative source of energy to maize in production of fish feed for a profitability aquaculture enterprise.

\section{REFERENCES}

Adegeye, A.J. and J.S. Dittoh, 1982. Essentials of Agricultural Economics. Impact Publishers, Ibadan, ISBN: 976-30481.21-14, pp: 113-116.

Adejinmi, O.O., 2000. The chemical composition and nutritional potential of soldiers larvae (Hermetioa elucens) in poultry ration. Poult. Sci., 2: 301-31D.

Akinfala, E.O. and O.O. Tewe, 2001. Utilization of whole cassava plant in the diets of growing pigs in the tropics. Livest. Res. Rural Dev., 13: 5-12.

Akinrotimi, O.A, U.U. Gabriel, N.K. Owhonda, D.N. Onunkwo, J.Y. Opara, P.E. Anyanwu and P.T. Cliffe, 2007. Formulating an environmentally friendly fish feed for sustainable aquaculture development in Nigeria. Agric. J., 2: 606-612.

Bekibele, D., E.S. Erondu and A.T. Gbulubo, 2006. OPtimum crude protein requirement of the catfish, Chrysichthys nigrodigitatus. J. Fish. Int., 1: 40-43.
Booth, M.A. and G.L. Allan, 2003. Utilization of digestilible nitrogen and energy from four agricultural ingredients by juvenile silver perch Bidyanus bidyanus. Aquac. Nutr., 9: 317-326.

Chalorwang, G., N. Dela and P. Janzloquet, 2000. Digestibility in fish: Improved device. Aquaculture, 200: 116-125.

Eyo, A.A., 2003. Fundamentals of Fish Nutrition and Diet Development: An Overview. In: Fish Feed Development and Feeding Practices in Aquaculture, Eyo, A.A. (Ed.). FISON, Lagos, Nigeria.

Eyo, A.A., 2004. Fundamentals of fish nutrition and diet development: An overview. Proceeding of the National Workshop on Fish Feed Development and Feeding Practices in Aquaculture, Sept. 15-19, FISON, Lagos, Nigeria, pp: 1-33.

Fagbenro, O.A., M.A.K. Smith, and A.I. Amoo, 2001. Acha (Digitari exilis stapf) meal compared with maize and sorghum meals as a dietary carbohydrate source for Nile tilapia (Oreochromis nilotius L.). Isr. J. Aquac., 52: 3-10.

Fasuyi, A.O. and V.A. Aletor, 2005. Protein replacement value of cassava (Manihot esculenta, Crantz) leaf protein concentrate (CLPC) in broiler starter: Effect on performance, muscle growth, haematology and serum metabolites. Int. J. Poult. Sci., 4: 339-349.

Gabriel, U.U., O.A. Akinrotimi, P.E. Anyanwu, D.O. Bekibele and D.N. Onunkwo, 2007. Locally produced fishfeed: Potential for aquaculture development in Subsaharan Africa. Afr. J. Agric. Res., 2: 287-295.

Ijaiya, A.T., O.O.A. Fasanya and A.B. Ayanwale, 2002. Reproductive performance of breeding does fed maize and fermented cassava peel meal. Proceedings of 27th Annual Conference Nigeria Society for Amimal Production, March 17-21, Federal University of Technology, Akure, Nigeria, pp: $249-252$.

Jamu, D.M. and O.A. Ayinla, 2003. Potential for the development of aquaculture in Africa. NAGA WorldFish Centre Quarterly, 26: 3-9.

Jiang, Z., 2001. Ingredient variation: Its impact and management. Adv. Nutr. Technol., 20: 20-31. 
Jinyasataporn, A., U. Kanto, S. Juttupornpony and W. Chow, 2000. Substitution of Cassava for Com in C. gariepinus Diets. In: Cassava for Animal Feed Project 1999 Annual Report, Houncer, R.H. (Ed.). Thai Tapioca Development Institute, Bangkok, Thailand, pp: 450.

Odunsi, A.A., A.A. Onifade and S.O. Oyewole, 2001. Utilization of cassava peel meals with or without sheabutter fat in diets of egg-type chickens. Indian J. Anim. Sci., 20: 31-36.

Olagunju, F.I., I.O. Adesiyan and A.A. Ezekiel, 2007. Economic viability of cat fish production in Oyo State, Nigeria. J. Hum. Ecol., 21: 121-124.

Olatunde, A.A., 1996. Effect of supplementation of soyabean diet with $\mathrm{L}$ and $\mathrm{D}, L$. methionrne on the growth of mud fish clarias anguillers. Nig. J. Biotechnol., 9: 9-16.

Olukunle, O., 2006. Nutritive potential of sweet potato peel meal and root replacement value for maize in diets of African catfish (Clarias gariepinus) advanced fry. J. Food Technol., 4: 289-293.
Olukunle, O.A., 1996. The nutritional potentials of processed sesame indicum in the diets of Clarias gariepinus Burchell, 1822). Ph.D. Thesis, Department of Wildlife and Fisheries Management, University of Ibadan, Ibadan.

Olurin, K.B.E., A.A. Olujo and O.A. Olukoya, 2006. Growth of African catfish Clarias gariepinus fingerlings, fed different levels of cassava. W. J. Zool., 1: 54-56.

Osuigwe, D.I., A.I. Obejezie and G.C. Onuoha, 2005. Some haematological changes in hybrid catfish (Heterobranchus longifilis $\mathrm{x}$ Clarias gariepinus) fed different dietary levels of raw and boiled jackbean (Canavalia ensiformis) seed meal. Afr. J. Biotechnol., 4: 1017-1021.

Tewe, O.O., 2004. Cassava for Livestock Feed in Sub-Saharan Africa. Food and Agriculture Organization of the United Nations, Rome, Italy, pp: 64 . 